\title{
Learning from the real practices of users of a smart carpooling app
}

\author{
Sonia Adelé ${ }^{*}$ D and Corinne Dionisio
}

\begin{abstract}
Aim: This paper explores the real practices of users of a smart carpooling application that learns their mobility habits and predicts their future trips to propose relevant matches.

Method: A combination of usage data and interviews analysis allows us to explore the commuter experience from registration to the first and the next shared rides.

Findings: The results highlight the shortcomings associated with human factors in carpooling and with humansmart system interactions. They show that perceptions of practical constraints and poor counterparts are the major reasons for difficulty in incorporating carpooling into daily mobility. Psychosocial barriers take different forms at different steps of the carpooling experience (search for information or guarantees about other users, the necessity of conversing with others, much uncertainty about how to behave). The fact that the service is smart amplifies these problems and reduces the desire to carpool again because it creates new misunderstandings (i.e., the user does not understand what the system vs. the other users do) and discomfort in relation to other riders (no answer, too many refusals, necessity of refusing, negative carpool experience, or concern over proposing a bad carpool). Despite these difficulties, the users perceive carpooling as a good solution and a positive human experience when the matching is accurate. We propose some recommendations to overcome the identified difficulties.
\end{abstract}

Keywords: Smart carpooling, Application, User practices, Practical, Psychosocial, Interviews, Usage data

\section{Introduction}

Individual mobility has undergone changes in recent years, and many millennials (born between 1983 and 2000) have adopted a car-free way of life [41]. This shift is in line with several trends: growing urbanization, the opening of the field of possibilities with new technologies for mobility, the emergence of the functional economy [34] and the sharing economy, an economic crisis, and more concern about sustainability. It seems to be a breeding ground for innovative mobility services that depart from the usual modes of travel. In this context, carpooling has found new life. Although this mode of transport is not truly new [16], it is returning to the mobility landscape in a new form enabled by the Internet and mobile applications [7]. Many traditional and new providers are entering the market with

\footnotetext{
* Correspondence: sonia.adele@univ-eiffel.fr
}

COSYS-GRETTIA, Univ Gustave Eiffel, IFSTTAR, 5 bd Descartes, F-77454 Marne-la-Vallée, Cedex 2, France the idea of reducing the number of cars on the roads by increasing their seat occupancy rate. This approach is highly relevant because, for example, $72 \%$ of French people use cars for their commute [1], and the vast majority of commuters travel alone in their car. However, the problem of attracting enough users to make such a service viable is not new. As early as 1977, a report highlighted the relative success of carpooling [16]. Currently, in France, the modal share of carpooling for commuters is $10 \%$ of the total kilometres travelled, and $4.5 \%$ of workers carpool every day [1].

In Article L. 1231-15 of the French Transport Code, dated March 2013, "Carpooling is the joint use of a land motor vehicle by a non-professional driver and one or more passengers for a common journey". Depending on the study, the definition of carpooling includes, for instance, long-distance or short-distance trips; shared trips within a family, called "fampool" [22]; shared trips 
between strangers; or stable carpool groups within a company, called "coworker carpool". From a practical point of view, carpooling is implemented in various ways: through informal contacts; through a specific matching service that is most often digital [7]; or through physical meetings at a carpooling stop or by the wayside to enable riders to use high-occupancy-vehicle lanes in ad hoc carpooling, also known as "slugging" [37]. We are specifically interested in short-distance carpooling supported by a digital platform, principally used to commute, and involving matching between strangers. Indeed, this type of service seems to have the greatest potential impact on the number of cars on the road and fewer constraints for the users. Our study focuses on the application (app) Karos, which is dedicated to daily carpooling; the app is based on machine learning and is available in France. The smartphone app learns the user's trips and then proposes carpooling "opportunities". Thus, the search for a relevant carpooler is processed by different algorithms. This service is similar to what Clavel and Legrand [9] called dynamic carpooling. It allows the quick realization of a carpool using mobile Internet and geolocation technologies, algorithms and matching rules, and it offers a payment function. However, Karos also offers intelligent matching features and has been awarded 8 times for its breakthrough innovation. At the time of this research, several carpooling applications for short trips exist in France, but none of them proposed smart functionalities (for example, for those based on mobile applications: Wayz Up, OuiHop). For this reason, the form of carpooling proposed by Karos is a particularly interesting field of study because it combines carpooling-specific issues and issues related to the interactions between humans and smart systems.

The objective of the study presented in this paper is to focus on real practices with a smart carpooling app and to address the practical and psychosocial barriers that must be overcome to improve a daily carpooling service and to promote its adoption. This paper is divided into four sections. The first section focuses on existing works about human factors in carpooling and in smart systems. The second section describes the design of our empirical research. The third section presents the results, which are discussed in the fourth section. Finally, the conclusion section describes the overall contributions of the study.

\section{Literature review}

\subsection{Human factors and carpooling}

In the literature, studies on carpooling are devoted to a multitude of factors, notably including technical optimization. Some researchers affirm that although the practical dimensions play an undeniable role, the psychosocial dimensions play a greater role in carpooling use [16, 24]. A large number of studies specifically target the psychosocial dimensions of carpooling (Table 1).
Their aim is uniformly to highlight the explanatory factors that allow us to understand why people use or do not use carpooling. One domain of study concerns users' motivations.

The economic advantage is the subject of a certain consensus within the scientific community over time and place $[6,19,33]$. Among the secondary advantages are a certain conviviality [6], addressing ecological concerns [33], and maintaining or restoring a positive selfimage [14]. Research also highlights perceived practical constraints, such as having to make a detour, taking an unusual or unknown route, adapting the departure time, and spending time organizing the carpool. Créno and Cahour [12] referred to organizational risks such as having difficulty finding the meeting place or having to wait for other carpoolers. Some studies affirmed a 5-min limit as the acceptable time for a detour [10, 22]. Bonsall, Spencer, and Teng [6] showed the crucial role of triptime compatibility and the difficulty of participating for those who have flexible work hours. They also found that detailed road network characteristics are extremely important because they influence the ease of realizing the trip (congested areas, difficult routes), determining whether carpooling is acceptable from the driver's point of view.

Many studies address the role of attitude as an antecedent of intention to participate in carpooling. Different determinants explain attitudes towards carpooling: personal attributes such as enjoyment of socializing, commitment to community, reciprocity, and altruism [3], attitude towards the environment, car use and public transportation [15], and trust [4]; and contextual attributes, such as convenience, reliability, pleasure, comfort, and expected time and economic benefits. Most of the works studying attitudes compare carpoolers and noncarpoolers $[15,19,24]$ and conclude that carpoolers have more positive attitudes. Bachmann et al. [4] also propose descriptive norms, perceived behavioural control, and personal norms as determinants of intention to use a carpooling service but do not find a link between a positive attitude towards carpooling and increased carpooling intention.

Finally, some researchers are interested in the psychosocial barriers that could prevent people from using this transport mode: privacy concerns, aversion to the loss of freedom in leaving a personal vehicle or transporting someone else, the perceived risk of sharing a ride with a stranger, and forced sociability while sharing an intimate space. Regarding privacy concerns, the recording of data by the carpooling provider is seen as a barrier during registration or use [24, 32]. The second barrier, aversion to the loss of freedom, is frequently highlighted [19, 33], sometimes as the main barrier [16]. This feeling varies according to the user's role in the car [24]. The third 
Table 1 Summary of the considered literature about carpooling (in the text below by order of appearance)

\begin{tabular}{|c|c|c|c|c|c|c|}
\hline Reference & Date & Place & Sample & Method & Aim & $\begin{array}{l}\text { Carpool } \\
\text { studied }\end{array}$ \\
\hline $\begin{array}{l}\text { Bonsall, } \\
\text { Spencer \& } \\
\text { Tang [6] }\end{array}$ & 1984 & $\begin{array}{l}\text { West } \\
\text { Yorkshire, } \\
\text { England }\end{array}$ & $\begin{array}{l}265 \text { commuter members of } \\
\text { the carpooling programme }\end{array}$ & Surveys, interviews & $\begin{array}{l}\text { Assess the implementation of a } \\
\text { carpooling programme }\end{array}$ & $\begin{array}{l}\text { Short } \\
\text { distance } \\
\text { work-related }\end{array}$ \\
\hline $\begin{array}{l}\text { Horowitz \& } \\
\text { Sheth [19] }\end{array}$ & 1976 & Chicago, USA & $\begin{array}{l}822 \text { commuters ( } 323 \\
\text { carpoolers, } 382 \text { solo drivers, } \\
117, \text { public transport users) }\end{array}$ & Survey & $\begin{array}{l}\text { Perceived advantages and } \\
\text { disadvantages of carpooling }\end{array}$ & $\begin{array}{l}\text { Short } \\
\text { distance, } \\
\text { work-related }\end{array}$ \\
\hline Richard [33] & 2011 & Nîmes, France & $\begin{array}{l}67 \text { students non-carpoolers, } \\
105 \text { students ( } 54 \% \text { of } \\
\text { carpoolers }^{\mathrm{a}} \text { ) }\end{array}$ & Surveys & Attitudes and perceived barriers & Unclear \\
\hline $\begin{array}{l}\text { Debroux } \\
{[14]}\end{array}$ & 2018 & France & 23 carpoolers (drivers) & Autobiographical interviews & $\begin{array}{l}\text { Define the determinants of } \\
\text { engagement in the practice of } \\
\text { carpooling }\end{array}$ & Work-related \\
\hline $\begin{array}{l}\text { Créno \& } \\
\text { Cahour [12] }\end{array}$ & 2014 & France & $\begin{array}{l}25 \text { long-distance carpoolers } \\
\text { (6 drivers, } 19 \text { passengers) }\end{array}$ & Explicitation interviews & $\begin{array}{l}\text { Characterize user experience of } \\
\text { carpoolers (process of building } \\
\text { trust) }\end{array}$ & $\begin{array}{l}\text { Planned } \\
\text { long } \\
\text { distance }\end{array}$ \\
\hline Li et al. [22] & 2007 & $\begin{array}{l}\text { Dallas \& } \\
\text { Houston, USA }\end{array}$ & $\begin{array}{l}310 \text { carpoolers }^{\mathrm{b}} 4324 \text { solo } \\
\text { drivers }\end{array}$ & Reuse of survey data & Reasons for choosing to carpool & $\begin{array}{l}\text { Short } \\
\text { distance, } \\
\text { work-related }\end{array}$ \\
\hline $\begin{array}{l}\text { Covivo SAS } \\
\& \text { CGI [10] }\end{array}$ & 2011 & Isère, France & $\begin{array}{l}488 \text { members of the } \\
\text { carpooling programme }\end{array}$ & Survey \& usage data & $\begin{array}{l}\text { Experimentation in dynamic } \\
\text { carpooling }\end{array}$ & $\begin{array}{l}\text { Short } \\
\text { distance, } \\
\text { mainly } \\
\text { work-related }\end{array}$ \\
\hline $\begin{array}{l}\text { Amirkiaee \& } \\
\text { Evange- } \\
\text { lopoulos [3] }\end{array}$ & 2018 & $\begin{array}{l}\text { Southwestern } \\
\text { USA }\end{array}$ & $\begin{array}{l}300 \text { students ( } 4 \% \text { using a } \\
\text { carpooling app) }\end{array}$ & Scenario-based survey & $\begin{array}{l}\text { Role of attitudes in the intention } \\
\text { to use carpooling }\end{array}$ & $\begin{array}{l}\text { Short } \\
\text { distance, } \\
\text { study- } \\
\text { related }\end{array}$ \\
\hline $\begin{array}{l}\text { Delhomme } \\
\& \\
\text { Gheorghiu } \\
{[15]}\end{array}$ & 2016 & France & $\begin{array}{l}1207 \text { French drivers }(52.5 \% \\
\text { of carpoolers }^{\mathrm{C}} \text { ) }\end{array}$ & Survey & $\begin{array}{l}\text { Investigate the main } \\
\text { determinants of the use of } \\
\text { carpooling }\end{array}$ & Unclear \\
\hline $\begin{array}{l}\text { Bachmann, } \\
\text { Hanimann } \\
\text { \& Artho [4] }\end{array}$ & 2018 & Switzerland & $\begin{array}{l}342 \text { people (181 passengers } \\
\text { and } 161 \text { drivers }\end{array}$ & Survey & $\begin{array}{l}\text { Link between attitudes and } \\
\text { intention/carpool use }\end{array}$ & Unclear \\
\hline $\begin{array}{l}\text { Margolin, } \\
\text { Misch, \& } \\
\text { Stahr [24] }\end{array}$ & 1978 & $\begin{array}{l}\text { Washington, } \\
\text { USA }\end{array}$ & $\begin{array}{l}516 \text { people ( } 49.6 \% \text { of } \\
\text { carpoolers) }\end{array}$ & Focus groups Surveys & $\begin{array}{l}\text { Compare the carpooling attitudes } \\
\text { of carpoolers versus solo drivers }\end{array}$ & $\begin{array}{l}\text { Short } \\
\text { distance, } \\
\text { work-related }\end{array}$ \\
\hline $\begin{array}{l}\text { Radke, et al. } \\
{[32]}\end{array}$ & 2011 & Australia & A small group of persons & Interviews Focus groups & $\begin{array}{l}\text { Develop an app that takes into } \\
\text { account privacy and security }\end{array}$ & $\begin{array}{l}\text { Ad hoc } \\
\text { carpooling }\end{array}$ \\
\hline $\begin{array}{l}\text { Dueker, Bair } \\
\text { \& Levin [16] }\end{array}$ & 1977 & $\begin{array}{l}\text { lowa City, } \\
\text { USA }\end{array}$ & $\begin{array}{l}\text { Sample of employees of } \\
\text { three big companies }\end{array}$ & Synthesis of research conducted & $\begin{array}{l}\text { Identify the barriers and } \\
\text { motivations for carpooling }\end{array}$ & $\begin{array}{l}\text { Short } \\
\text { distance, } \\
\text { work-related }\end{array}$ \\
\hline $\begin{array}{l}\text { Nielsen } \\
\text { et al. [30] }\end{array}$ & 2015 & Denmark & $\begin{array}{l}47 \text { persons ( } 7 \% \text { of } \\
\text { carpoolers }^{d} \text { ) }\end{array}$ & $\begin{array}{l}\text { Semi-structured interviews } \\
\text { Focus groups }\end{array}$ & $\begin{array}{l}\text { Elements that influence the } \\
\text { adoption of carpooling. Define } \\
\text { market segments. }\end{array}$ & $\begin{array}{l}\text { Short } \\
\text { distance }\end{array}$ \\
\hline $\begin{array}{l}\text { Mote \& } \\
\text { Whitestone } \\
{[28]}\end{array}$ & 2011 & $\begin{array}{l}\text { Washington, } \\
\text { USA }\end{array}$ & 12 slugs and drivers & Semi-structured interviews & $\begin{array}{l}\text { Interest in the practice of } \\
\text { slugging to highlight the impact } \\
\text { of social context on } \\
\text { transportation }\end{array}$ & $\begin{array}{l}\text { Slugging (ad } \\
\text { hoc } \\
\text { carpooling) }\end{array}$ \\
\hline $\begin{array}{l}\text { Deakin et al. } \\
\text { [13] }\end{array}$ & 2010 & Berkeley, USA & $\begin{array}{l}58 \text { people (focus group) } \\
444 \text { persons (survey) }\end{array}$ & $\begin{array}{l}\text { Mobility data Survey Focus } \\
\text { groups }\end{array}$ & $\begin{array}{l}\text { Providing insights about a } \\
\text { dynamic carpooling service } \\
\text { features }\end{array}$ & $\begin{array}{l}\text { Short } \\
\text { distance } \\
\text { dynamic } \\
\text { carpooling }\end{array}$ \\
\hline Chaube $[8]$ & 2010 & $\begin{array}{l}\text { Blacksburg, } \\
\text { USA }\end{array}$ & 125 people & Survey Usability study & $\begin{array}{l}\text { Understanding the perception of } \\
\text { trust in a software carpooling } \\
\text { application to design it }\end{array}$ & $\begin{array}{l}\text { Short } \\
\text { distance, } \\
\text { commute- } \\
\text { related }\end{array}$ \\
\hline $\begin{array}{l}\text { Créno \& } \\
\text { Cahour [11] }\end{array}$ & 2015 & France & $\begin{array}{l}25 \text { carpoolers } 25 \text { non- } \\
\text { carpoolers }\end{array}$ & $\begin{array}{l}\text { Semi-structured and } \\
\text { explicitation interviews }\end{array}$ & $\begin{array}{l}\text { Identify the perceived risks, the } \\
\text { sources of trust and mistrust }\end{array}$ & $\begin{array}{l}\text { Planned } \\
\text { long- }\end{array}$ \\
\hline
\end{tabular}


Table 1 Summary of the considered literature about carpooling (in the text below by order of appearance) (Continued)

\begin{tabular}{|c|c|c|c|c|c|c|}
\hline Reference & Date & Place & Sample & Method & Aim & $\begin{array}{l}\text { Carpool } \\
\text { studied }\end{array}$ \\
\hline & & & & & & $\begin{array}{l}\text { distance } \\
\text { carpooling }\end{array}$ \\
\hline $\begin{array}{l}\text { Gardner \& } \\
\text { Abraham } \\
{[18]}\end{array}$ & 2007 & $\begin{array}{l}\text { Brighton \& } \\
\text { Hove, England }\end{array}$ & 19 car commuters & Interview & Identify reason for driving & NC \\
\hline $\begin{array}{l}\text { Schaeffer } \\
\text { et al. [35] }\end{array}$ & 1988 & USA & $\begin{array}{l}46 \text { drivers ( } 19 \text { carpoolers } \\
\text { and } 27 \text { single drivers) }\end{array}$ & $\begin{array}{l}\text { Physiological measures (heart } \\
\text { rate and blood pressure) Survey } \\
\text { Performance measurement }\end{array}$ & $\begin{array}{l}\text { Measurement of the effect of } \\
\text { morning rush hour commuting } \\
\text { for single and carpool drivers }\end{array}$ & $\begin{array}{l}\text { Short } \\
\text { distance } \\
\text { work-related }\end{array}$ \\
\hline Allen [2] & 2009 & USA & 6 commuters & Interview & $\begin{array}{l}\text { Identify the barriers of carpooling } \\
\text { to design an online service }\end{array}$ & $\begin{array}{l}\text { Short } \\
\text { distance } \\
\text { commute- } \\
\text { related }\end{array}$ \\
\hline
\end{tabular}

${ }^{a}$ The author points out that the majority of these carpoolers do not really carpool in the strict sense (i.e., with an unknown person)

${ }^{\mathrm{b}} 75 \%$ of them practice fampooling

'The part of fampooling is not specified

${ }^{d} A$ carpooler is a person who carpools at least four times a month

barrier, sharing a ride with a stranger, has been widely cited and studied [16, 24, 33]. This fear can refer to two distinct phenomena: the perception of any risk $[12,30]$ and discomfort linked to forced sociability with a stranger in an intimate space. The experience of carpooling seems to inhibit the feeling of insecurity [28]. Other guarantees could reduce this feeling: 1) information allowing users to consider real proximity (i.e., a group who work for the same company) or symbolic proximity (i.e., a group of the same gender) $[16,28], 2)$ the possibility of choosing the carpooler $[6,13,33]$, or 3 ) a reputation provided by peers $[8,13]$. Créno and Cahour [12] highlight a meticulous process of choosing a carpooler and interpreting the available information. In general, when the carpooler takes a more precise form, that is, information is available about him or her, the more familiar he/she seems and the more willing users are to share a ride [6]. Mote and Whitestone [28] borrowed the concept of the "familiar stranger" from Milgram [27] in studying slugging users. Regarding the fourth psychosocial barrier, the intrusion of a stranger in an intimate sphere or the obligation to be sociable, Créno and Cahour [11] described the fear of not having common conversational topics or being forced to converse. Being alone in a car is a more positive experience than sharing the car space [18], especially because of the ability to control the internal environment of the car [35]. Carpooling is socially demanding because it implies interpersonal relations in a semi-public situation whose codes are unknown [2, 24]. In slugging [28], the most emblematic rule is that the passenger must not start a conversation, which suggests that slugging makes it possible to increase the pragmatic personal benefits (saving time and/or money) while limiting the social constraints. Moreover, it seems that rules for best practices help to clarify a fuzzy situation and reduce social discomfort.
Methodologically, most of the existing studies rely on surveys by questionnaire. Those questionnaires are based on a priori attitudes and intentions of use [3], and the study sometimes includes a sample of carpoolers [15, 30]. Only a few studies use qualitative methods that allow a deeper understanding of what carpoolers experience during carpooling [12, 14, 28]. Those studies use different types of observations or interviews, in-depth semi-structured interviews, biographical interviews, or "resituating" explicitation interviews to help participants remember the entire process from choosing a ride to the end of the shared ride.

\subsection{Human factors and smart systems}

Smart systems include multi-theory processes to replicate human behaviours to accomplish a task or a combination of tasks. They have long existed in certain applications, such as spam filters and article suggestions. The intelligence lies in the ability of the system to perceive and infer the needs of the user according to the current situation with the least intervention by the user. Smart systems have sensors to collect information or use information captured by other systems and are related to ubiquitous computing, as conceptualized by Weiser [43]. Their central issue is the integration of everyday activities. Smart systems can include machine learning techniques based on algorithms that can learn from data, build models from large numbers of examples, and use the models to make predictions or decisions rather than following explicit instructions. The machine seeks to learn relevant patterns of user behaviour, and users seek to understand and control a complex and malleable system.

To the best of our knowledge, no study has focused on a smart carpooling system; however, many studies on other areas of application, such as housing, have been 
Table 2 Summary of the considered research papers about smart systems (in the text below by order of appearance)

\begin{tabular}{|c|c|c|c|}
\hline Reference & Date & Studied system & Method \\
\hline Kidd et al. [20] & 1999 & Smart home & Summary of different works \\
\hline $\begin{array}{l}\text { Fréjus \& Guibourdenche } \\
\text { [17] }\end{array}$ & 2012 & Smart home & $\begin{array}{l}\text { In realistic laboratory: usage data, video recording, interview, } \\
\text { questionnaire ( } 15 \text { people) } \\
\text { At home: video recording, self-confrontation interviews (5 } \\
\text { households) }\end{array}$ \\
\hline Yang \& Newman [44] & 2013 & Smart home (the Nest thermostat) & $\begin{array}{l}\text { Interviews ( } 23 \text { people from } 19 \text { households) } \\
\text { Three-week diary study ( } 10 \text { households) }\end{array}$ \\
\hline $\begin{array}{l}\text { Mennicken \& Huang } \\
\text { [26] }\end{array}$ & 2012 & Smart home & $\begin{array}{l}\text { Interviews ( } 7 \text { smart home professionals and } 15 \text { people from } \\
10 \text { households) }\end{array}$ \\
\hline Stumpf et al. [39] & 2009 & Automatic email classification system & Think-aloud experimental task, questionnaire (13 students) \\
\hline Kulesza et al. [21] & 2009 & Automatic email classification system & $\begin{array}{l}\text { Cooperative debugging task } \\
\text { Dialogue analysis (11 pairs of students) }\end{array}$ \\
\hline $\begin{array}{l}\text { Tullio, Dey, Chalecki \& } \\
\text { Fogarty [40] }\end{array}$ & 2007 & System to predict manager interruptibility & $\begin{array}{l}\text { Six-week field study ( } 4 \text { managers, } 8 \text { direct reports) } \\
\text { Interviews ( } 8 \text { office workers) }\end{array}$ \\
\hline $\begin{array}{l}\text { Lim, Dey \& Avrahami } \\
\text { [23] }\end{array}$ & 2009 & $\begin{array}{l}\text { System that determines whether the person is } \\
\text { performing a physical activity }\end{array}$ & Experiments: interaction, test, survey (211 persons) \\
\hline
\end{tabular}

carried out since the late 1990s (Table 2). Originally concentrated in laboratories [20], studies are increasingly focusing on ecological situations [17, 44]. Existing studies make it possible to identify issues related to the acceptability of this type of system: utility, understandability, and trust. Regarding utility, users consider a system smart only if it does what they cannot do more efficiently [26]. This issue is difficult to resolve because of the difficulty in predicting human behaviour without error. Indeed, human behaviour is often unpredictable and changeable [5]. The key is for a system to be smart enough to differentiate patterns and exceptions [44]. It is possible to improve the prediction quality by establishing sound parameters or by interacting with users when the uncertainty is high to validate the prediction or decision parameters [21, 39]. The user sees this type of interaction as positive [39]. Concerning understandability, many pitfalls are associated with the mismatch between the users' mental model and the system model [40]. For Norman [29], a mental model is an internal representation of the things with which people interact, and it has a functional utility. Such a model is a good predictor of the quality of the interaction between a user and a system. To accept and efficiently use a technical system, the user must develop a mental model of the system that is consistent with its actual functions. In other words, the system should make sense to the user. In the case of smart systems, intelligibility and manageability are difficult to achieve [5, 23]. A user wants to understand what is happening to maintain control [36]. Some studies have proposed ways to explain the decision-making rules of the system to users [21] by providing "why" and "why not" answers [23]. If users fail to build an efficient mental model, they feel frustrated and trust the system less. For carpooling, trust is often used as a criterion of acceptance of smart systems. Trust is based on reliability, shared values and aims, transparency, and intelligibility. The more autonomous the system, the greater the level of trust must be high [38]. Mayer, Davis, and Schoorman ([25], p.712) define trust as "the willingness to be vulnerable to the actions of another party based on the expectation that the other party will perform a particular action important to the trustor, irrespective of the ability to monitor or control the other party". Previous studies show that building trust is difficult [44].

In summary, smart systems face challenges, and no commonly accepted solution has been identified. Such systems generally have a high level of desirability but a high risk of disillusionment [44]. A consensus exists on the need for ethnographic studies dealing with the situated real activity of future users $[20,40]$ and for interviews to understand the domain in which the smart system is used [31].

\subsection{Aim and content of the paper}

The main goal of this paper is to present the results of a study on a smart daily carpooling app to understand the barriers faced by registered users. ${ }^{1}$ We propose to complement the existing research by focusing on the phase that separates registration, which we might consider intention to use, from the actual realization of the first or the following shared ride. Furthermore, we propose an in-depth study based on between-method triangulation, because such studies are still lacking. Based on real

\footnotetext{
${ }^{1}$ Throughout the article, the word "user" is used when we do not know whether individuals are actually carpooling with the application. The word "carpooler" is used when users carpool with the application as a driver or passenger. An indication of the role in carpooling is given where relevant.
} 
practices, this study investigates the practical and psychosocial barriers that must be overcome to improve a smart daily carpooling service and to promote its adoption.

\section{Methodology}

\subsection{Context of the study}

This study is the result of a partnership with the startup Karos, which wished to obtain a deeper understanding of app-supported carpooling to bring the proposed service closer to users' mobility needs. Karos has offered a smart carpooling service since the end of 2015. The service is exclusively usable with a smartphone and was made available on Android and Apple. Although available throughout France, it was principally used in the Ile-de-France region (80\% of the users) (Fig. 1).

When the research was conducted in 2016, the carpooling service functioned as follows. The app continuously collected and computed all the short-distance trips (with all purposes) made by a user (in time and space) to understand users' mobility habits and predict the next move. The user chose his/her role in the carpool from three possibilities: driver, passenger, or either (driver or passenger). With this information, the app automatically provided tailored carpooling options for the next three trips. The user, for whatever role he/she chose, saw a list of "opportunities" and chose to make a "request" of another user (Fig. 2).

These opportunities were shown without either the driver or the passenger confirming that the predicted trip would really occur. It was also possible to manually add unpredicted trips. The travel time used for matching and presented to users was estimated on the basis of an average time per kilometre per type of geographical area

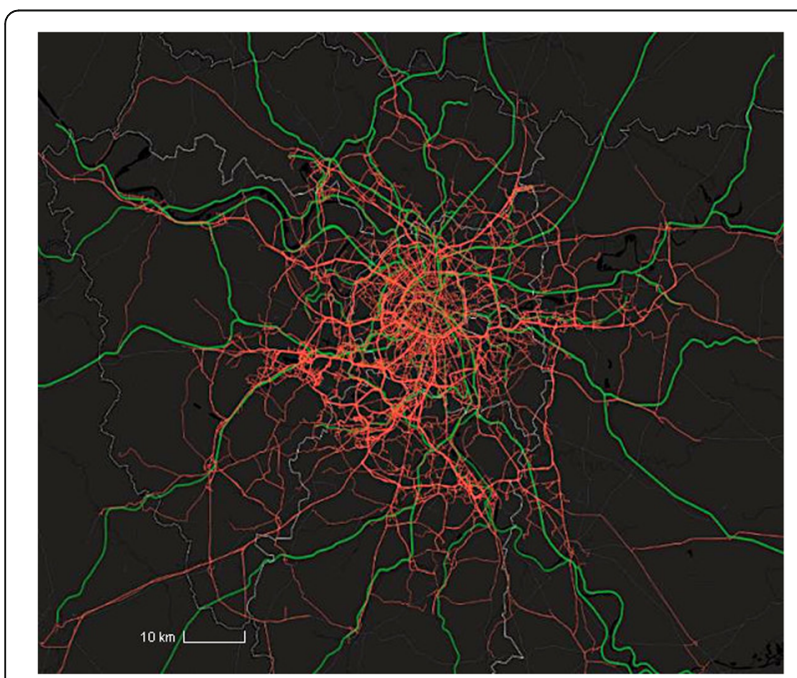

Fig. 1 Map of the trips proposed by Karos (in red) and the rail network (in green) in lle-de-France in 2016-2017@ Karos (urban or rural). Every user had a profile with different mandatory and optional information available (first name, photo, preferences, peer evaluations, company for the users working for a corporate customer of the app). A chat option was available to talk with other users or with Audrey, the customer service representative. Financially speaking, the app charges $€ 0.10$ per kilometre to the passenger (with a minimum of $€ 1.5$ per trip), which are paid in full to the driver. If the passenger holds a Navigo Pass (Ile-de-France public transport card), two trips per day are free (from July 2016).

Given the competitive nature of the sector, it is extremely difficult to accurately estimate the use of the application. For example, we do not know the exact number of carpooling trips made each day.

Few figures are available, and they are rather vague (Karos, 2016):

- 10,000 regular active users every month (the definition of "active users" is not provided

- 20,000 proposed trips each week

- 7 possible carpoolers available for each trip

- 2 trips per week on average per carpooler

- $18 \mathrm{~km}$ on average per trip

\subsection{Methods}

The study used four complementary methods: three trace studies and a method based on material that was built specifically for the study (interviews). The usage data were provided by Karos, which complies with the directives of the National Commission for Data Protection and Liberties (CNIL). No personal data have been provided except the email addresses of users to contact. This file has been declared to the CNIL as well as the data collected during the interviews.

\subsubsection{Chat conversations between users $(n=285)$}

The chat system was used by $5 \%$ of active users (i.e., they had opened the app at least once in the previous week) to talk to other users. We obtained 4 months of data representing 285 conversations (an exchange that took place over one or more days with or without an answer from the recipient). The discussion partners were qualified by their first name and whether they worked for a corporate customer of the app that has purchased a carpooling service for its employees. ${ }^{2}$ Some timestamped information allowed us to qualify the outcome of the conversation (request for a carpool, acceptance of a request, realization of a carpool). No specific information was provided to the users regarding the use of conversations for this research. However, it is specified in the

${ }^{2}$ When the user is in this case, a logo of his company appears on his profile. For other users, there is no company affiliation. 


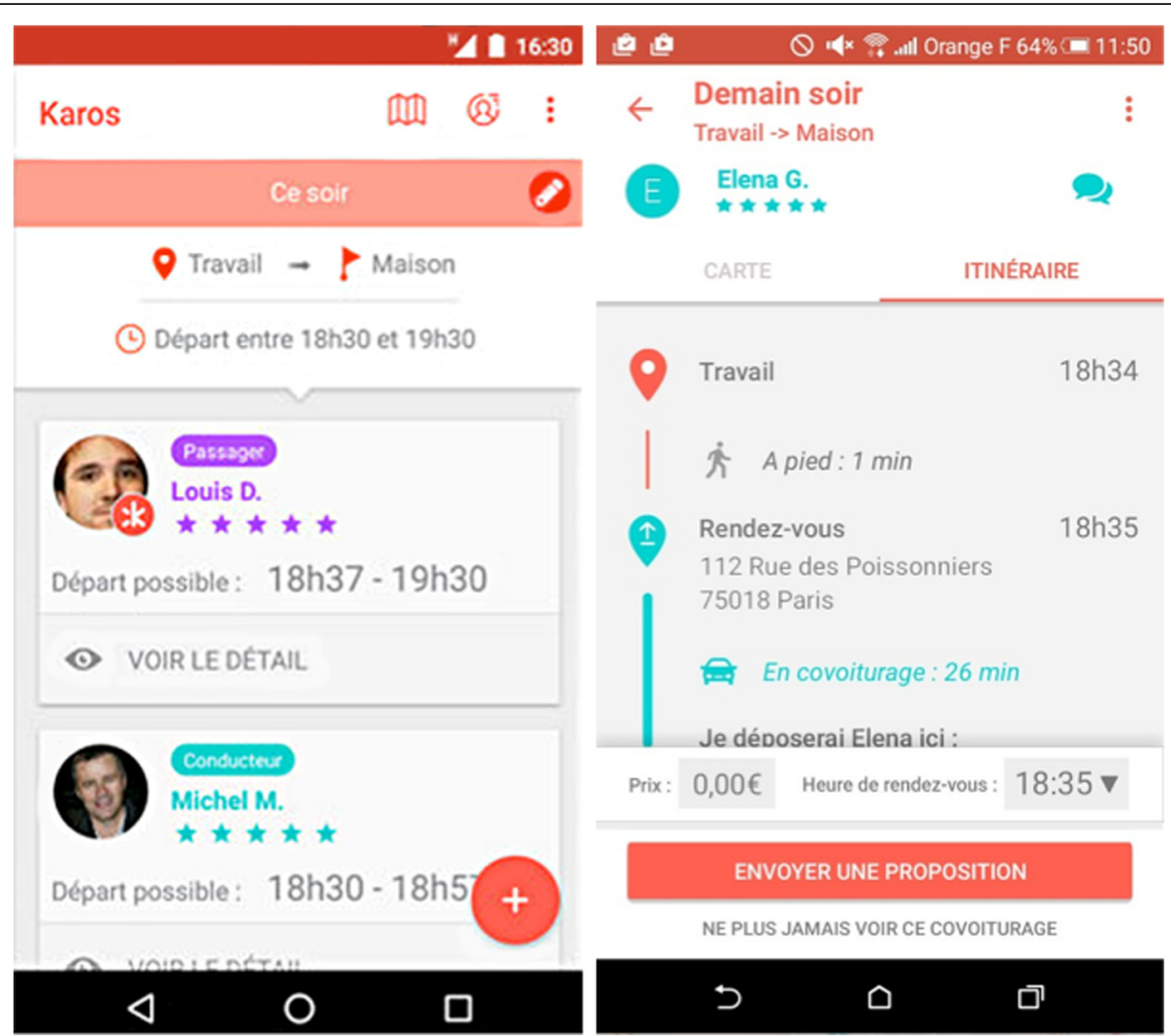

Fig. 2 Screenshots of the smart carpooling app (2016)@ Karos

application's general terms and conditions of use that all data related to the use of the application may be used. We analysed the data with different methods: a thematic content analysis (What do the users speak about?) and an individual analysis (Who speaks with whom and with what results?).

\subsubsection{Chat conversations between users and customer service $(n=973)$}

Of the users, 9\% communicated with customer service through chat. We obtained a database of 6 months of conversations $(n=973)$ and analysed the content of the conversations.

\subsubsection{Refusal of opportunities presented by the app ( $n=$ 1085)}

As mentioned above, an opportunity is a match proposed by the system to the users. The users can indicate whether they do not want to see the match. We obtained 6 months of data that included 1085 refusals. For each, we knew the role (driver or passenger) of the user who refused the opportunity and the reason for the refusal. A single-choice question offered four responses: route, carpooler, time, and money. An optional open field was also available to comment on the answer. We analysed the responses to the question (specified by the comments) and linked it with the role of the user who refused the opportunity.

\subsubsection{Interviews $(n=21)$}

We interviewed carpoolers who had previously shared a ride but had not done so in the past month. The startup provided a list of 172 users email addresses from all over France. The carpoolers received an email explaining the aim and conditions of the interview, and 21 gave written consent and were interviewed (Table 3). The interviews lasted approximately $30 \mathrm{~min}$ and were split into four parts: before the app and registration process, the first moments on the app, the first interactions with other users and the experience(s) of carpooling. To explore the lived experience, we used an "explicitation interview" method [42]. Those interviews were recorded and retranscribed for thematic analysis. The sample was composed of 11 males and 10 females living in urban

Table 3 Characteristics of the sample interviewed $(n=21)$

\begin{tabular}{llll}
\hline & Male & Female & Total \\
\hline Passenger & 2 & 6 & 8 \\
Either & 1 & 1 & 2 \\
Driver & 8 & 3 & 11 \\
Total & 11 & 10 & 21 \\
\hline
\end{tabular}


areas (18 from Ile-de-France and 3 from other places) and with an average age of 40 (sd. 10.85). The participants were mainly in higher socio-professional categories (3 students, 1 employee, 2 technicians, 1 unemployed, 14 managers). The interviewees had carpooled with the following distribution: 5 once, 4 twice, 3 three times, and 9 more (i.e., from five times to a practice of several days a week over several months).

\section{Results}

\subsection{What do users talk about through chat?}

We analysed three types of messages separately (Fig. 3): unanswered messages, answered messages that did not result in a carpool, and those that did result in a carpool.

The analysis of the content of the messages highlighted three major problems, of which two were directly linked to the way the smart app functioned. The first problem concerned the availability of the proposed opportunity. For example, for $34 \%$ of the unanswered messages and $87 \%$ of the answered messages without a shared ride, the user explained that he/she was temporarily or permanently unavailable (unable to take that trip at that moment, holidays, personal constraints) or had spatiotemporal incompatibility (route, detour, time). It should be noted, however, that the majority $(56 \%)$ of the conversations that resulted in carpooling evoked the same problems of unavailability. In those cases, the chat feature was a good place to negotiate the postponement of carpooling from 1 to 15 days. The second problem for $25 \%$ of the unanswered messages was misunderstanding the difference between an opportunity (a system prediction) and a request (an action of the other carpooler). That is, one-quarter of unsuccessful messages showed that users thought they had been asked by someone even though they saw only information generated automatically by the system. Those cases had different clues in our database: no request had been formulated, AND the user began a negotiation OR apologized OR said he/she disagreed with the trip OR thanked the other user for the request OR asked questions about the other user's expectations. This misunderstanding is less present in unsuccessful conversations (7\%) and totally absent in conversations leading to a shared journey. The last problem was the lack of response from the other user. Of people attempting to make contact with another user about a trip, $54 \%$ received no answer.

\subsection{Who talks with whom through the chat, and what are the outcomes?}

We are able to identify the gender of the two interlocutors for 280 conversations. Our analysis showed that men spoke together more than other combinations (woman-woman, man-woman, woman-man). Conversations between men represented $49 \%$ of all the conversations, but only $2.5 \%$ of all the 280 conversations were interactions between men and led to a shared ride (ratio of 19.6). The conversations that led to carpooling were initiated mainly by women who spoke to men. Twenty percent of all the conversations were initiated by a woman speaking to a man, and $3.5 \%$ of all the 280 conversations were initiated by a woman speaking to a men and led to a shared ride (ratio of 5.7) (Fig. 4).

If the users worked for partnering companies, their possibility of sharing rides improved. Those users constituted $45 \%$ of those who shared a ride, whereas they comprised only $31 \%$ of the users in our database.

\subsection{Why do users contact customer service?}

Of the messages, $42 \%$ did not request help. They were greetings in response to the welcome message (38\%), attempts to seduce Audrey (3.5\%), or verification that Audrey was human (less than 1\%). User difficulties were the subject of $58 \%$ of the messages: $40 \%$ related to use (payment, modification of different parameters, use of some function), $20 \%$ related to the smart aspect of the app (smart functions, proposed detour or route, proposed time and day, proposed user), $15 \%$ related to

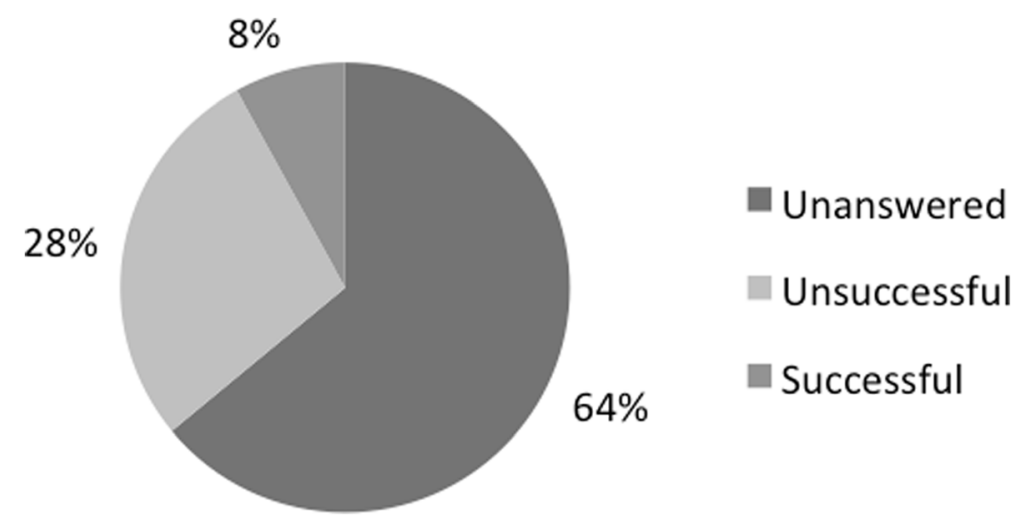

Fig. 3 Distribution of the type of conversations in the database (successful messages being those that led to a shared ride) 


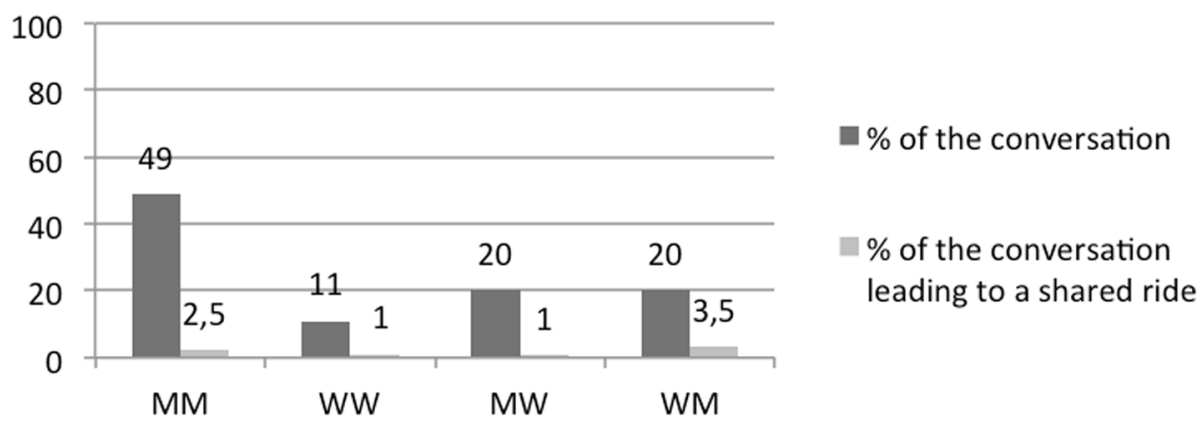

Fig. 4 Proportion of overall conversations $(n=280)$ by gender and by outcome of the conversation (M=Man, W=Woman)

requests for new functions, and $16 \%$ related to complaints of too few opportunities or too few answers.

\subsection{Who refuses carpooling opportunities, and why?}

Our analyses showed that drivers accounted for $86 \%$ of the refusals (Table 4). In $80 \%$ of the cases, the reason was the route, and $13 \%$ disagreed with the time.

Comments from 83 users helped us understand exactly what topics the reasons cover. "Time" covers the day, departure time, and duration of the trip. "Route" covers a route that does not fit the user's habits, a longer route in time or $\mathrm{km}$ (congested or mountain road), excessive walking time to reach the departure point, and a multimodal route when the user does not want to take public transport. "Carpooler" covers profiles with errors, users with an improper attitude (no response, seducer, professional driver), or incompatible status (both users wanting to be the driver).

A statistical analysis confirmed a significant link between the user status in the shared ride and the reason for the refusal $\left(\mathrm{x}^{2}(3)=88.15 ; p<.001\right)$ (Table 2). The reason "route" was overrepresented among drivers, and the reasons "carpooler" and "time" were overrepresented among passengers.

\subsection{Corpus analysis of the interviews}

We proceeded to an exhaustive content analysis of the data corpus by theme (Table 5). Most of the themes were linked to the steps of the user experience (from registering to the shared ride and after), and one was linked with the barriers associated with the smart functions, as they negatively affected the global experience of the user. We then separately quantified and qualified the

Table 4 Distribution of refusal reasons by role $(n=1085)$

\begin{tabular}{lllllll}
\hline & & \multicolumn{2}{l}{ Reasons } & & & Total \\
\cline { 3 - 6 } & & Carpooler & Money & Route & Time & \\
\hline Role & Driver & $3 \%$ & $2 \%$ & $\mathbf{8 4 \%}$ & $11 \%$ & $86 \%$ \\
& Passenger & $\mathbf{1 5 \%}$ & $1 \%$ & $54 \%$ & $\mathbf{2 9} \%$ & $14 \%$ \\
\multirow{2}{*}{ Total } & & $5 \%$ & $2 \%$ & $80 \%$ & $13 \%$ & $100 \%$ \\
\hline
\end{tabular}

ideas provided by drivers, passengers, and individuals with either role.

\subsubsection{Registration}

The users unanimously considered the registration a positive step with different qualifiers: "easy" $(n=11)$, "rapid" $(n=7)$, and good support from customer service $(n=5)$.

\subsubsection{Initial use}

The first contact with the app was not so positive. Opportunities for carpooling were scarce $(n=3)$ or irrelevant $(n=10)$ : "I see nobody [on the app]. Because there is nobody on this trip" ( $\mathrm{N}^{\circ} 11$, male, driver, 32); "It's not at all on my way" ( $\mathrm{N}^{\circ} 6$, male, driver, 37$)$. Only 5 users were satisfied with the proposals made by the system. The interviews also showed that carpooling is more frequently initiated by a passenger $(n=3)$ than by a driver $(n=2)$ : "During this period, I had some lists that I didn't necessarily decide to proceed with, [...] I was waiting for the request" ( $\mathrm{N}^{\circ} 2$, male, driver, 46).

Almost all users chose to ask or to accept a request for practical reasons $(n=13)$ : "There was indeed a picture, but I don't care about it [...]. It doesn't matter, age, or origin, or religion, I don't care" $\left(\mathrm{N}^{\circ} 10\right.$, female, passenger, 44). For the driver, the trip should meet three conditions: it should fit the usual route with an important common part, not have too many detours, and take place at the right time with more or less flexibility: "It turns out that I was able to get an opportunity that is close enough in terms of the journey, so it worked fine" $\left(\mathrm{N}^{\circ} 7\right.$, female, driver, 47$)$. For the passenger, the time and complexity of the trip were of greater interest. Passengers were not interested in trips with many public transport parts: "I try to ask the person to drop me as close as possible to my destination" ( $\mathrm{N}^{\circ} 16$, female, passenger, 23). Only 3 users were interested in the profile of the other user (gender, age, guarantees, photo): "It's true that the photo allows us to imagine who the person is" $\left(\mathrm{N}^{\circ} 9, \mathrm{fe}-\right.$ male, either, 22). 
Table 5 Frequency of the appearance of themes in the corpus by role in shared rides (with a single count being added for the presence of the theme in an interview even if the theme appeared many times in the interview)

\begin{tabular}{|c|c|c|c|c|c|c|}
\hline Themes & Sub-themes & Content & $\begin{array}{l}\text { Drivers } \\
(n=11)\end{array}$ & $\begin{array}{l}\text { Passengers } \\
(n=8)\end{array}$ & $\begin{array}{l}\text { Either } \\
(n=2)\end{array}$ & $\begin{array}{l}\text { Total } \\
(n=21)\end{array}$ \\
\hline \multirow[t]{3}{*}{ Before using the app } & \multirow[t]{3}{*}{ Registering } & Rapid & 4 & 3 & 0 & 7 \\
\hline & & Easy & 5 & 6 & 0 & 11 \\
\hline & & Good support & 3 & 2 & 0 & 5 \\
\hline \multirow[t]{7}{*}{ Initial use } & \multirow[t]{3}{*}{ Opportunities } & None or too few & 2 & 0 & 1 & 3 \\
\hline & & Relevant & 2 & 3 & 0 & 5 \\
\hline & & Irrelevant & 7 & 3 & 0 & 10 \\
\hline & \multirow[t]{4}{*}{ First request } & Made & 2 & 3 & 0 & 5 \\
\hline & & Received & 5 & 1 & 2 & 8 \\
\hline & & Interest in the profile & 1 & 1 & 1 & 3 \\
\hline & & Interest in the trip & 7 & 5 & 1 & 13 \\
\hline \multirow[t]{4}{*}{ First contacts with other users } & \multirow[t]{2}{*}{ Chat exchanges } & Increased trust & 1 & 1 & 1 & 3 \\
\hline & & Practical conditions & 7 & 5 & 3 & 15 \\
\hline & \multirow[t]{2}{*}{ Deceptions } & No answer & 5 & 1 & 0 & 6 \\
\hline & & Many negative answers & 1 & 0 & 1 & 2 \\
\hline \multirow[t]{9}{*}{ Shared ride } & \multirow[t]{2}{*}{ Before the ride } & Confirmations & 2 & 5 & 0 & 7 \\
\hline & & Difficulties in finding other user & 3 & 3 & 0 & 6 \\
\hline & \multirow[t]{7}{*}{ During the ride } & Pleasant conversation & 10 & 6 & 2 & 18 \\
\hline & & Radio off & 3 & 0 & 1 & 4 \\
\hline & & Positive feeling & 4 & 3 & 0 & 7 \\
\hline & & Negative feeling & 0 & 2 & 0 & 2 \\
\hline & & Evocation of another try & 3 & 1 & 0 & 4 \\
\hline & & Congestion/lost time & 3 & 1 & 0 & 4 \\
\hline & & Anxiety about taking a new route & 1 & 0 & 0 & 1 \\
\hline \multirow[t]{3}{*}{ Next shared ride } & \multirow[t]{3}{*}{ Changes made } & Meeting place & 2 & 2 & 0 & 4 \\
\hline & & Verifications of detours & 0 & 1 & 0 & 1 \\
\hline & & Conversation topics & 1 & 0 & 0 & 1 \\
\hline \multirow[t]{10}{*}{ Not repeated use } & \multirow[t]{2}{*}{ Not advantageous } & Time (longer trip) & 1 & 2 & 1 & 4 \\
\hline & & Money (cost-benefit analysis) & 2 & 0 & 0 & 2 \\
\hline & \multicolumn{2}{|c|}{ Personal or professional change } & 1 & 1 & 1 & 3 \\
\hline & \multirow[t]{2}{*}{ Only use occasionally } & Part-time user & 1 & & 0 & 1 \\
\hline & & Flexible workplace and hours & 1 & 1 & 0 & 2 \\
\hline & Few possibilities & & 5 & 5 & 0 & 10 \\
\hline & \multirow[t]{4}{*}{ Discomfort } & Asking others for a detour & 0 & 3 & 0 & 3 \\
\hline & & Uncomfortable with a person & 0 & 2 & 0 & 2 \\
\hline & & Uncomfortable to ask & 1 & 2 & 0 & 3 \\
\hline & & Uncomfortable to be late/take excessive travel time & 2 & 0 & 0 & 2 \\
\hline \multirow[t]{4}{*}{ Problems with the smart app } & \multirow[t]{2}{*}{ Understandability } & Why a result is obtained & 3 & 2 & 0 & 5 \\
\hline & & Who chooses what & 2 & 0 & 0 & 2 \\
\hline & Utility & Did not understand me & 1 & 1 & 0 & 2 \\
\hline & Trust & Did things wrong without my consent & 2 & 2 & 1 & 5 \\
\hline
\end{tabular}




\subsubsection{First contact with other users}

This step is often deceptive. The other user did not answer $(n=6)$ or gave negative answers $(n=2)$, which were experienced as difficulties: "I wanted to carpool to go to Paris. First, she did not answer me. A week later, I tried again, and she simply refused" ( $\mathrm{N}^{\circ} 1$, male, passenger, 22). Drivers were more concerned about deception $(n=6)$.

Before the first shared trip, the chat was heavily used, but for different reasons. The majority of the users used chat to discuss schedule or meeting place $(n=15)$ : "I proposed another schedule, and she asked me if I could a little earlier. I told her ok, I'll hurry up" (N²0, male, driver, 49). One user in each category used chat to increase trust in the other party: "It's certain that we'll have more confidence in each other after an exchange of a few words on the chat" ( $\mathrm{N}^{\circ} 9$, female, either, 22).

\subsubsection{First shared ride}

Just before the ride, 7 users sent or received confirmations on the chat: "A little message saying, 'I'm arriving'. [.... It shows that the person has taken carpooling into account and that he is on the road" ( $\mathrm{N}^{\circ} 13$, female, passenger, 56). Six users experienced difficulty meeting the other; in those cases, they called the other, but a fuzzy negative impression remained: "There was a misunderstanding about the meeting point. That may have cooled him off. [....] But we didn't talk about it again, so I don't know" ( $\mathrm{N}^{\circ} 6$, male, driver, 37).

During the ride, the great majority $(n=18)$ of the users appreciated conversation. They found the trip "Great, because it was delightful. We could have a conversation; he works in the same field as me. So it was really nice" ( $\mathrm{N}^{\circ} 8$, male, passenger, 34$)$. Four drivers (3 drivers, 1 either) turned the radio off. However, trips also evoked negative feelings $(n=7)$ : passengers felt uncomfortable during the ride $(n=2)$ : "It's very delicate because it's a moment when we enter the intimacy of the other person in a way. I say to myself, can we talk or not? If we risk talking, we also take the risk of not appreciating the other person. [....] It's very delicate, and I was a little embarrassed. [....] I felt a little intrusive actually" $\left(\mathrm{N}^{\circ} 10\right.$, female, passenger, 48$)$, the ride was lengthened by congestion $(n=4)$, and one driver was anxious because of the unknown route. In a few cases (3 drivers, 1 passenger), the users mentioned the possibility of sharing a ride another time.

\subsubsection{Next shared ride}

With the repetition of the experience $(n=16)$, the users improved their practices in changing the meeting place $(n=4)$, talking about more personal subjects $(n=1)$, and checking whether the driver truly found the detour acceptable $(n=1)$.

\subsubsection{Reasons not to carpool again}

The users had different reasons for not sharing a ride again. Some reasons were clearly specific to drivers: sharing rides was not economically advantageous given the organizational constraints $(n=2)$, and they were uncomfortable wasting the passenger's time because of congestion when the person had paid for the trip $(n=2)$ : "I was wondering why people will give me money if I will not save them time and money on top of their Navigo Pass" (N6, male, driver, 37). Some reasons were clearly specific to passengers: they felt that more time was lost than saved by using carpooling instead of public transport $(n=2)$ : "Even if the trip is more enjoyable, I don't gain much more time [compared with a trip by public transport], and I find it hard to win $10 \mathrm{~min}^{\prime}\left(\mathrm{N}^{\circ} 14\right.$, female, passenger, 27), they did not feel "comfortable asking someone to make a detour" $\left(\mathrm{N}^{\circ} 17\right.$, female, passenger, 40) $(n=3)$, or they felt uncomfortable with the other person $(n=2)$. Other common reasons were personal or professional changes $(n=3)$, having a flexible workplace or schedule $(n=2)$, not having many opportunities $(n=$ $10)$, or being uncomfortable asking the first time or after a refusal or no response $(n=3)$ : "I carpooled with Gaëlle, but she did not make any more contact. She is still there, but as she hasn't come back, I don't dare too either. I don't really know. I think maybe I shouldn't... And there's Charlene, with whom I talked once, but she wasn't interested. I didn't search any more for schedules and routes because there was another guy who seemed to fit better, and he hadn't refused yet" ( $\mathrm{N}^{\circ} 6$, male, driver, 37).

\subsubsection{Problems with the smart app}

In 7 cases, users did not understand the function of the app, which created situations of discomfort with other users: "For these requests, I couldn't clearly understand [...] how the person was able to solicit me when I had a completely different route from her. We had tried to exchange, but we could not manage to understand each other" ( $\mathrm{N}^{\circ} 6$, male, driver, 37) and "I don't understand why these people are proposed to me because I don't like hearing people's refusals after 4 tries. I understand that the route that is proposed to me for the driver isn't really the road that the driver wanted to take. I'm not sure. It's a hypothesis. I didn't understand" ( ${ }^{\circ} 17$, female, passenger, 40).

Two users thought that the system was not able to understand their mobility habits, and 5 users developed mistrust because "sometimes it tends to generalize and do things inappropriately without our consent" $\left(\mathrm{N}^{\circ} 9\right.$, female, either, 22). "Yes, on the application, the problem is that they always put a trip for the day after that isn't necessarily made. So sometimes we receive proposals when we aren't available, and we must cancel the request" ( $\mathrm{N}^{\circ} 16$, female, passenger, 23). 


\section{Discussion}

The study presented in this paper offers a contribution to the understanding of the practical and psychosocial barriers experienced by the users of a smart carpooling app. We focused on real practices to provide recommendations to improve a carpooling service based on a smart app. Use data obtained through the carpooling provider and interviews offered a view of different steps of the user experience. We determined that people who wanted to carpool encountered many difficulties, some of which were associated with the smart functions of the app.

First, we highlighted the importance of practical constraints in choosing the carpooler, already put forward by Bonsall et al. [6]: respect for the usual route and more or less flexible travel time. The idea was to decrease the constraints related to return on investment not being great enough (money, time, or pleasure). The importance of these perceived constraints contradicted the findings of some studies [16, 24]. Some users remained affected by psychosocial barriers and needed to search for reassurance, as shown by Créno and Cahour [12]. The analyses show that the introduction of an intelligent system in carpooling does not replace human relations in the process of building trust. Indeed, the chat is a particularly appreciated and useful tool. The carpoolers used the chat feature to negotiate, to become acquainted before asking each other about carpooling, and to reassure a passenger just before a ride. Always with the idea of overcoming psychosocial barriers, working for a corporate customer of the app can be perceived as a guarantee for those users who attribute importance to the profile of the user and need reassurance. This guarantee had already been shown by Duecker et al. [16] and Mote and Whitestone [28]. The fear of strangers still exists, especially for passengers (the reason "carpooler" accounted for $15 \%$ of the refusals); however, according to Mote and Whitestone [28], it may disappear with practice, as only a few interviewees mentioned this issue. We share with Bachmann et al. [4] the idea that there is not always a link between a positive attitude toward carpooling and an increased intention to practice, and we assume that practical and psychosocial constraints could explain why, as the constraints hindered the perceived behavioural control.

Second, according to Créno and Cahour [11] and Margolin et al. [24], we show that carpooling is socially and emotionally demanding, and not only during the shared trip. At each step of his/her journey, the user asks him/ herself what should be done. Should I ask or wait for the other to ask? What should I do after a refusal? How do I resolve a misunderstanding about the meeting place? Is it better to talk or not talk in the car? Who should ask again after the trip according to what was said in the car? There is a need for best practice guidelines. Some informal norms appear in real practice that could be a basis for such a guide. We found that a request from a woman to a man is more likely to lead to a shared ride. This effect could be explained by the fact that women are often passengers. A passenger asking a driver could be more efficient. Our results should have been crossed with the status of the user in the shared ride, but we had no information about this dimension in our database. Some clues in our results could indicate that information. We did not manage to have the same numbers of male and female drivers and passengers in our sample of interviewees. The content of the interviews also showed that passengers are more likely to initiate carpooling.

Third, our analyses showed that smart carpooling, initially envisaged as a way of simplifying carpooling by eliminating user interventions, aggravates the difficulty inherent in carpooling. Because the system predicts trips that are not actually made without any verification by stakeholders, contrary to what is recommended by Belloti and Edwards [5], many requests remain unanswered. The users experience much frustration and discouragement owing to a lack of answers or many negative answers. Additionally, the service provider may set matching rules based on an unrealistic road network (i.e., the predicted times are incorrect). By calculating travel time exclusively on the basis of distance and type of area (urban or not), matching is often inappropriate from the point of view of both driver and passenger, as shown by the reason to refuse an opportunity and by the interviews. The driver is familiar with these roads that he or she regularly uses and knows where he or she is likely to get caught in a traffic jam. In some cases, the passenger may have already chosen the "wrong" carpool when he/she discovers the problem. He or she realizes, in retrospect, that his or her travel time is equal to or worse than the time spent travelling by public transport. The smart app also does not propose an optimized meeting point, and the users must take time to understand each other's situation and to negotiate. The smart matching also increases misunderstanding between users, which create fuzzy negative feelings (for example, when a trip that is not made is proposed and the driver misses a message and does not respond). As shown by Lim et al. [23], there is a need for intelligibility and manageability that the system fails to fulfil. Users fail to understand each other's expectations of the others (i.e., they do not understand whether the system or another carpooler has made a proposal), and they experience many uncomfortable situations that prevent them from trying again. They are not sure to be punctual, they feel themselves losing time during the trip, or they feel uncomfortable complicating someone else's trip. Consequently, some users question the utility of the smart function of the system or do not trust the system but 
continue to use it. Similar results have been obtained by Mennicken and Huang [26] and Yang and Newman [44] on intelligent housing. Some recommendations, already proposed by Kulesza et al. [21] and Stumpf et al. [39], have been proposed on the balance between the intelligence implemented in the application and the expectations of users. Some of them have been implemented by Karos:

- Give a lesser role to the system in choosing the route and allow the driver to indicate his/her preferred route. This makes it possible to optimize traffic conditions during carpooling without having access to real-time traffic condition information.

- Ask the user regularly about the relevance of the predicted trips or give the user the possibility of adjusting the predictions weekly (instead of the next three trips). This further avoids the proposal of matches on unrealized trips.

- Provide the possibility of disabling the scheduling and route prediction feature. This feature is particularly relevant when users have the same number of regular and irregular trips.

A new study could confirm whether those improvements are truly efficient from the user's point of view. ${ }^{3}$

This study could have been improved in quality by using the results obtained in a questionnaire, which would have allowed repeated measurements to test the permanent evolution of the application in the direction of our recommendations. A questionnaire could also have made it possible to address, for the same individual, the relative importance of the perceived practical and psychosocial constraints. This was not temporally possible during the research contract.

\section{Conclusions}

This study, which is based on the real practices of the users of a smart carpooling app, highlights the role of perceived practical constraints in the definition of "good" carpooling. It also shows how psychosocial constraints operate in all steps of the user experience and are worsened by the mode of operation of the smart system. Today, artificial intelligence is not able to serve as a substitute for the user in the organization of carpooling. The processes involved are too complex to leave a weak role for the end-user. Our results even show that the smart mode of functioning (prediction of trips that are not made, unrealistic travel time) creates new difficulties and introduces more misunderstandings, uncertainties,

\footnotetext{
${ }^{3}$ The increasing use of the application seems to show user satisfaction, because Karos announced, in 2019, 1 million shared trips in 4 years and 175,000 users.
}

and disappointments. The evolution of the app should continue in the direction of finding a good balance between the user and the artificial intelligence actions. Our study also highlights positive aspects of carpooling (conviviality) and of the app, which succeeds in providing a satisfactory service to its users despite its initial shortcomings. As carpooling becomes increasingly based on technology, our findings can contribute to improving and promoting carpooling to decrease the number of cars on the road. For future research, there is an interest in taking into account the real practices of end-users to understand their choice to carpool.

\section{Acknowledgements}

We wish to express our gratitude to AJE, who edited this paper for language. We thank all the volunteers who gave their time for the interviews. We also thank the three volunteer reviewers who, through their wise advice, helped us to improve this article.

\section{Authors' contributions}

SA conducted the interviews, analysed the data and made a major contribution to writing the manuscript. CD retranscribed the interviews, compiled the bibliography and corrected the manuscript. All authors read and approved the final manuscript.

\section{Funding}

This research was funded by Karos in the framework of a research contract (RP1-F16016).

\section{Availability of data and materials}

The datasets generated and/or analysed during the current study are not publicly available due to contractual restrictions.

\section{Competing interests}

Karos funded this research in the framework of a research contract between IFSTTAR and KAROS. The start-up was not implicated in the design of the study, the data analysis and interpretation, nor the writing of the manuscript. The authors declare that they have no competing interests.

Received: 30 April 2019 Accepted: 19 May 2020

Published online: 03 June 2020

\section{References}

1. ADEME (2015). Leviers d'actions pour favoriser le covoiturage de courte distance, évaluation de l'impact sur les polluants atmosphériques et le CO2_Leviers d'actions, benchmark et exploitation de l'enquête nationale Transports et déplacements (ENTD) [Action levers to promote short-distance carpooling, impact assessment on air pollutants and CO2_Action levers, benchmarking and exploitation of the national transport and travel survey]Etude réalisée par INDIGGO et EnvirOconsult.

2. Allen, J. L. (2009). Human-center ridesharing - A sustainable solution. In Paper presented at CHI 2009. Conference. Boston: ACM Available at http:// www.jenniferleeallen.com/portfolio4_docs/1694JAllen.pdf.

3. Amirkiaee, S. Y., \& Evangelopoulos, N. (2018). Why do people rideshare? An experimental study. Transportation Research Part F: Traffic Psychology and Behaviour, 55, 9-24. https://doi.org/10.1016/j.trf.2018.02.025.

4. Bachmann, F., Hanimann, A., Artho, J., \& Jonas, K. (2018). What drives people to carpool? Explaining carpooling intention from the perspectives of carpooling passengers and drivers. Transportation Research Part F: Traffic Psychology and Behaviour, 59(A), 260-268. https://doi.org/10.1016/j.trf.2018. 08.022.

5. Bellotti, V., \& Edwards, K. (2001). Intelligibility and accountability: Human considerations in context-aware systems. Human-Computer Interaction, 16(2-4), 193-212. https://doi.org/10.1207/S15327051HCl16234_05.

6. Bonsall, P. W., Spencer, H., \& Tang, W. (1984). What makes a car-sharer? Transportation, 12(2), 117-114. https://doi.org/10.1007/BF00167372. 
7. Chan, N. D., \& Shaheen, S. A. (2012). Ridesharing in North America: Past, present, and future. Transport Reviews, 32(1), 93-112. https://doi.org/10.1080/ 01441647.2011.621557.

8. Chaube, V. (2010). Understanding and designing for perceptions of trust in rideshare programs. Blacksburg: Doctoral Thesis, Faculty of the Virginia Polytechnic Institute and State University.

9. Clavel, R., \& Legrand, P. (2009). Le covoiturage dynamique: Etude préalable avant expérimentation [Dynamic carpooling: Preliminary study before experimentation]. Lyon: Certu.

10. Covivo SAS et Conseil Général de I'Isère (2011). Expérimentation du covoiturage dynamique entre le plateau du Vercors et l'Agglomération Grenobloise [Experimentation of dynamic carpooling between the Vercors plateau and the Grenoble urban area]. Available at http://itinisere.fr/ftp/ documents_FR/rapport-final-public_ecovoiturage.pdf (consulté le 12/02/ 2013).

11. Créno, L., \& Cahour, B. (2015). Perceived risks and trust experience in a service of carpooling. In Proceedings of the 22nd ITS World Congress (paper ITS-2466).

12. Créno, L., \& Cahour, B. (2014, September). Chronicles of Lived Experiences for studying the process of trust building in carpooling. In Proceedings of the 2014 European Conference on Cognitive Ergonomics (Article n¹5, pp. 1-8). New York: ACM. https://doi.org/10.1145/2637248.2637255

13. Deakin, E., Trapenberg Frick, K., \& Shively, K. M. (2010). Markets for dynamic ridesharing? Case of Berkeley, California. Transportation Research Record, 2187, 131-137

14. Debroux, J. (2018). Les ressorts de l'engagement dans une pratique de consommation collaborative [The motivations for engagement in a collaborative consumer practice]. L'Homme \& la Société, 207(2), 185-217. https://doi.org/10.3917//hs.207.0185.

15. Delhomme, P., \& Gheorghiu, A. (2016). Comparing French carpoolers and non-carpoolers: Which factors contribute the most to carpooling? Transportation Research Part D: Transport and Environment, 42, 1-15. https:// doi.org/10.1016/j.trd.2015.10.014.

16. Duecker, K. J., Bair, B. O., \& Levin, I. P. (1977). Ride-sharing: Psychological factors. Transportation Engineering Journal of ASCE, 103(6), 685-692.

17. Fréjus, M., \& Guibourdenche, J. (2012). Analysing domestic activity to reduce household energy consumption. Work, 41(1), 539-548. https://doi.org/10. 3233/WOR-2012-0662-539.

18. Gardner, B., \& Abraham, C. (2007). What drives car use? A grounded theory analysis of commuters' reasons for driving. Transportation Research Part F: Traffic Psychology and Behaviour, 10(3), 187-200. https://doi.org/10.1016/j.trf. 2006.09.004.

19. Horowitz, A. D., \& Sheth, J. N. (1976). Ridesharing to work: A psychosocial analysis. In Working paper, University of Illinois at Urbana-Champaign.

20. Kidd, C. D., Orr, R., Abowd, G. D., Atkeson, C. G., Essa, I. A., Maclntyre, B. Mynatt, E., Starner, T. E., \& Newstetter, W. (1999). The aware home: A living laboratory for ubiquitous computing research. In: International workshop on cooperative buildings (pp. 191-198). Berlin, Heidelberg: Springer.

21. Kulesza, T., Wong, W. K., Stumpf, S., Perona, S., White, R., Burnett, M. M., Oberst, I. \& Ko, A. J. (2009, February). Fixing the program my computer learned: Barriers for end users, challenges for the machine. In: Proceedings of the 14th international conference on Intelligent user interfaces (pp. 187-196). New York: ACM. https://doi.org/10.1145/1502650.1502678

22. Li, J., Embry, P., Mattingly, S. P., Sadabadi, K. F., Rasmidatta, I., \& Burris, M. W. (2007). Who chooses to carpool and why? Examination of Texas carpoolers. Transportation Research Record, 2021(1), 110-117.

23. Lim, B. Y., Dey, A. K., \& Avrahami, D. (2009). Why and why not explanations improve the intelligibility of context-aware intelligent systems. In Proceedings of the SIGCHI Conference on Human Factors in Computing Systems (pp. 21192128). New York: ACM. https://doi.org/10.1145/1518701.1519023

24. Margolin, J. B., Misch, M. R., \& Stahr, M. (1978). Incentives and disincentives of ride sharing. Transportation Research Record, 673, 7-15.

25. Mayer, C., Davis, J. H., \& Schoorman, F. D. (1995). An integrative model of organizational trust. Academy of Management Review, 20(3), 709-734. https://doi.org/10.5465/amr.1995.9508080335.

26. Mennicken, S., \& Huang, E. M. (2012). Hacking the natural habitat: An in-thewild study of smart homes, their development, and the people who live in them. In International conference on pervasive computing (pp. 143-160). Berlin, Heidelberg: Springer.

27. Milgram, S. (1970). The experience of living in cities: A psychological analysis. Science, 167(3924), 1461-1468 https://www.jstor.org/stable/1728966.
28. Mote, J. E., \& Whitestone, Y. (2011). The social context of informal commuting: Slugs, strangers and structuration. Transportation Research Part A: Policy and Practice, 45(4), 258-268. https://doi.org/10.1016/j.tra.2011.01. 006.

29. Norman, D. A. (1983). Some observations on mental models. In D. Gentner \& A. L. Stevens (Eds.), Mental models (pp. 7-14). Hillsdale: Lawrence Erlbaum Associates Inc..

30. Nielsen, J. R., Hovmøller, H., Blyth, P. L., \& Sovacool, B. K. (2015). Of "white crows" and "cash savers:" a qualitative study of travel behavior and perceptions of ridesharing in Denmark. Transportation Research Part A: Policy and Practice, 78, 113-123. https://doi.org/10.1016/j.tra.2015.04.033.

31. Peffer, T., Pritoni, M., Meier, A., Aragon, C., \& Perry, D. (2011). How people use thermostats in homes: A review. Building and Environment, 46(12), 25292541. https://doi.org/10.1016/j.buildenv.2011.06.002.

32. Radke, K., Brereton, M., Mirisaee, S., Ghelawat, S., Boyd, C., \& Nieto, J. G (2011). Tensions in developing a secure collective information practice - the case of agile ridesharing. In P. Campos et al. (Eds.), Proceedings of the 13th IFIP TC 13 International Conference INTERACT 2011, Part II, LNCS, 6947 (pp. 524-532). Heidelberg: Springer.

33. Richard, I. (2011). Facteurs et processus psychosociaux du changement pour l'adoption de comportements pro-environnementaux: le cas du covoiturage [Psychosocial factors and processes of change for the adoption of proenvironmental behaviours: The case of carpooling]. Thèse de doctorat, Université de Provence - Université de Nîmes.

34. Rifkin, J. (2000). The age of access. New-York: Tarcher/Putman.

35. Schaeffer, M. H., Street, S. W., Singer, J. E., \& Baum, A. (1988). Effects of control on the stress reactions of commuters. Journal of Applied Social Psychology, 18(11), 944-957. https://doi.org/10.1111/j.1559-1816.1988. tb01185.x

36. Scholtz, J., \& Consolvo, S. (2004). Toward a framework for evaluating ubiquitous computing applications. IEEE Pervasive Computing, 3(2), 82-88. https://doi.org/10.1109/MPRV.2004.1316826.

37. Shaheen, S. A., Chan, N. D., \& Gaynor, T. (2016). Casual carpooling in the San Francisco Bay Area: Understanding user characteristics, behaviors, and motivations. Transport Policy, 51, 165-173. https://doi.org/10.1016/j.tranpol. 2016.01.003

38. Sheridan, T. B., \& Verplank, W. L. (1978). Human and computer control of undersea teleoperators. Cambridge: Massachusetts Institute of Technology, Man-Machine Systems Lab.

39. Stumpf, S., Rajaram, V., Li, L., Wong, W. K., Burnett, M., Dietterich, T., Sullivan, E., \& Herlocker, J. (2009). Interacting meaningfully with machine learning systems: Three experiments. International Journal of Human-Computer Studies, 67(8), 639-662. https://doi.org/10.1016/j.ijhcs.2009.03.004.

40. Tullio, J., Dey, A. K., Chalecki, J., \& Fogarty, J. (2007). How it works: a field study of non-technical users interacting with an intelligent system. In Proceedings of the SIGCHI Conference on Human Factors in Computing Systems (pp. 31-40). New York: ACM. https://doi.org/10.1145/1240624. 1240630

41. U.S. PIRG, Education Fund (2013). A new direction: Our changing relationship with driving and the implications for America's Future. Available at http://www.uspirg.org/sites/pirg/files/reports/A\%20New\%20Direction\%2 OvUS.pdf

42. Vermersch, P. (1994). L'entretien d'explicitation [The explicitation interview]. Paris: ESF.

43. Wieser, M. (1991). The computer for the 21th century. Scientific American, 265(3), 94-105.

44. Yang, R., \& Newman, M. W. (2013). Learning from a learning thermostat: lessons for intelligent systems for the home. In Proceedings of the 2013 ACM international joint conference on Pervasive and ubiquitous computing (pp. 93102). New York: ACM. https://doi.org/10.1145/2493432.2493489

\section{Publisher's Note}

Springer Nature remains neutral with regard to jurisdictional claims in published maps and institutional affiliations. 